\begin{tabular}{|l|l|l|}
\hline \multicolumn{2}{|c|}{ PublisherInfo } \\
\hline \hline PublisherName & $:$ & BioMed Central \\
\hline \hline PublisherLocation & $:$ & London \\
\hline \hline PublisherImprintName & $:$ & BioMed Central \\
\hline \hline
\end{tabular}

\title{
Articles selected by Faculty of 1000: nuclear microRNA processing; transposon mutagenesis in Helicobacter; Saccharomyces gene expression regulation; molecular convergent evolution; linkage disequilibrium in dogs
}

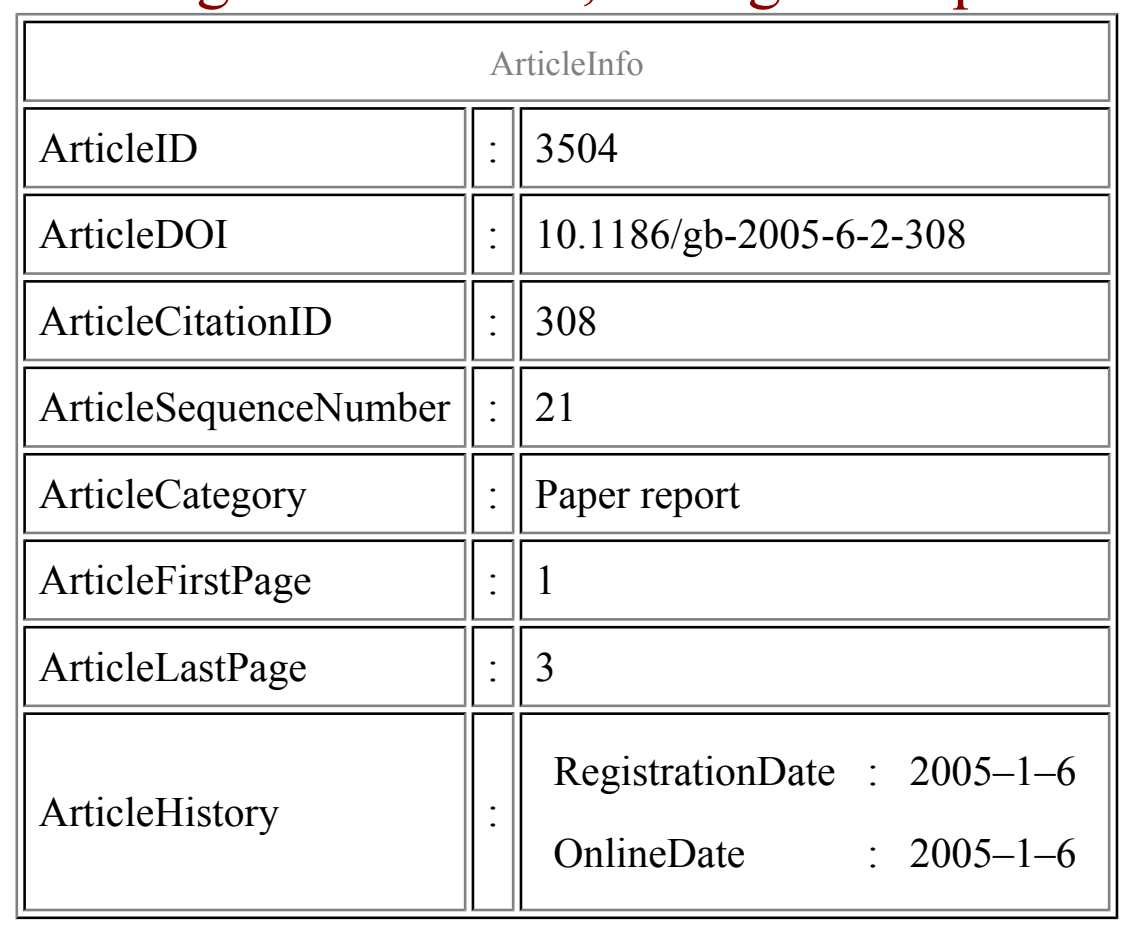




\begin{tabular}{|c|c|}
\hline ArticleCopyright & BioMed Central Ltd2005 \\
\hline ArticleGrants & \\
\hline ArticleContext & 130596622 \\
\hline
\end{tabular}

\section{Nuclear microRNA processing}

A selection of evaluations from Faculty of $\mathbf{1 0 0 0}$ covering nuclear microRNA processing; transposon mutagenesis in Helicobacter; Saccharomyces gene expression regulation; molecular convergent evolution; linkage disequilibrium in dogs.

Recognition and cleavage of primary microRNA precursors by the nuclear processing enzyme Drosha. Zeng Y, Yi R, Cullen BR. EMBO J 2004, November 25.

For the Faculty of 1000 evaluation of this article please see: http://genomebiology.com/reports/F1000/ gb-2005-6-2-308.asp\#Zeng

\section{Transposon mutagenesis in Helicobacter}

Global transposon mutagenesis and essential gene analysis of Helicobacter pylori . Salama NR, Shepherd B, Falkow S. J Bacteriol 2004, 186:7926-7935.

For the Faculty of 1000 evaluation of this article please see: http://genomebiology.com/reports/F1000/ gb-2005-6-2-308.asp\#Salama

\section{Saccharomyces gene expression regulation}

Post-transcriptional expression regulation in the yeast Saccharomyces cerevisiae on a genomic scale. Beyer A, Hollunder J, Nasheuer HP, Wilhelm T. Mol Cell Proteomics 2004, 3:1083-1092.

For the Faculty of 1000 evaluation of this article please see: http://genomebiology.com/reports/F1000/ gb-2005-6-2-308.asp\#Beyer 


\section{Molecular convergent evolution}

Convergent evolution of chromosomal sex-determining regions in the animal and fungal

kingdoms. Fraser JA, Diezmann S, Subaran RL, Allen A, Lengeler KB, Dietrich FS, Heitman J. PLoS Biol 2004, 2:e384.

For the Faculty of 1000 evaluation of this article please see: http://genomebiology.com/reports/F1000/ gb-2005-6-2-308.asp\#Fraser

\section{Linkage disequilibrium in dogs}

Extensive and breed-specific linkage disequilibrium in Canis familiaris . Sutter NB, Eberle MA, Parker HG, Pullar BJ, Kirkness EF, Kruglyak L, Ostrander EA. Genome Res 2004, 14:2388-2396.

For the Faculty of 1000 evaluation of this article please see: http://genomebiology.com/reports/F1000/ gb-2005-6-2-308.asp\#Sutter 